\title{
The Learning Effect of Blended Learning Based on Google Class Room and Initial Mathematics on Mathematic Representation and Resilience of Students in the Covid-19 Pandemic
}

\author{
$\underline{\text { Ayuni Khairiyyah }}{ }^{1}$, Mulyono $^{2}$, KMS. Muhammad Amin Fauzi ${ }^{3}$ \\ 1.2,3Universitas Negeri Medan, Indonesia \\ Email: 1ayuni.khairiyyah@gmail.com
}

\begin{abstract}
The success of students in taking mathematics lessons also greatly affects the factor of their initial mathematical abilities. Students' initial mathematical abilities are prerequisite abilities that students have before participating in the learning material that will be given. Therefore, students' initial knowledge is indeed an important part of students so that they have good abilities in solving a mathematical problem. (Depdiknas, 2005) states that students' initial knowledge is important for teachers to know before starting with their learning. In addition, students' initial mathematical abilities are also useful as a foothold in the beginning of each student's mathematics so that the teacher will find it easier determine a method or strategy that is suitable for use in the classroom so that the learning that is carried out will be more effective and efficient, (Fatimah, 2016: 13). The results of a preliminary study conducted on class VII teachers of SMPIT Ulil Albab Pematangsiantar shows that teachers have not identified students' initial mathematical abilities as a supporting factor for the success of learning mathematics. The same thing was expressed by (Suprapta, Suharta, $\mathcal{E}$ Irawan, 2016: 69) yang stated that most teachers tend to directly explain the subject matter to be discussed without wanting to know the ability of students' prior knowledge. Even though good learning provides opportunities for students to connect initial knowledge with new knowledge on the material being studied, train students' skills and abilities in the classroom.
\end{abstract}

Keywords: learning effect; blended learning; google classroom; initial mathematics

\section{Introduction}

Mathematics is an important part of the field of science. According to Irhamna (2020). Mathematics is a universal science. Mathematics is also seen as the queen of science The need for a logical mindset and proof in various lives is very necessary, but the fact shows that students' interest in mathematics is relatively low so that it is very rare to find students who understand logical proof well. When viewed from the point of view of classifying the field of science, mathematics is included in the exact sciences which require more proof than memorization. To be able to understand a mathematical subject, it requires the ability to represent mathematics related to the problems it faces. However, conditions in the field indicate that the representation skills of students are generally not maximal. Students' mathematical representation ability has not been maximized because mathematics is considered by students as one of the most feared and disliked subjects, it can be seen based on the results of the researcher's preliminary study of 24 class VIII students of SMPIT Ulil Albab Pematangsiantar which states that the maximum mathematical representation ability of students In the range of 1-100, the highest score obtained by students was only 60 and the lowest score was 20 with an overall average score of only 40 , and it was found that there were still many students whose mathematical representation skills were lacking. 
The success of students in taking mathematics lessons also greatly affects the factor of their initial mathematical abilities. To improve students' language reasoning skills, especially students of Mathematics Education and Accounting Education in order to continuously implement cooperative learning models (Sitepu, 2019). Students' initial mathematical abilities are prerequisite abilities that students have before participating in the learning material that will be given. mathematical is understood through critical thinking, and critical thinking is trained through learning mathematics (Lambertus in Nasution, 2020). Initial mathematical ability is very decisive in learning a subject matter new mathematics because mathematics is hierarchical. (Akramunnisa \& Sulestry, 2016: 47) revealed that in the processlearning, the teacher must pay attention to students' initial mathematical abilities in solving mathematical problems, because mathematical concepts are related to one another and form new, more complex concepts. Therefore, students' initial knowledge is indeed an important part of students so that they have good abilities in solving a mathematical problem. (Depdiknas, 2005) states that students' initial knowledge is important for teachers to know before starting with their learning. In addition, students' initial mathematical abilities are also useful as a foothold in the beginning of each student's mathematics so that the teacher will find it easier determine a method or strategy that is suitable for use in the classroom so that the learning that is carried out will be more effective and efficient, (Fatimah, 2016: 13). The results of a preliminary study conducted on class VII teachers of SMPIT Ulil Albab Pematangsiantar shows that teachers have not identified students' initial mathematical abilities as a supporting factor for the success of learning mathematics. The same thing was expressed by (Suprapta, Suharta, \& Irawan, 2016: 69) yang stated that most teachers tend to directly explain the subject matter to be discussed without wanting to know the ability of students' prior knowledge. Even though good learning provides opportunities for students to connect initial knowledge with new knowledge on the material being studied, train students' skills and abilities in the classroom.

\section{Review of Literatures}

\subsection{Blended Learning}

The combination of direct learning and technology-assisted internet-based learning achieves learning objectives which are expected to be blended learning (Fahrurrozi \& Majid, 2018: 57-67). Blended learning aims to present an effective and efficient learning process (Putra, 2015). The characteristics of traditional learning and electronic learning environments are integrated into blended learning (Rizkiyah, 2015: 40-49). Blended Learning is an onlinebased learning that combines classroom learning. This learning can be done at the same time and in different places. This learning strengthens learning in the classroom by utilizing today's technology learning.

Blended Learning is a combination of direct learning and online learning. Students must look for an active learning style according to themselves. This learning using the development of educational technology will strengthen the direct learning process (Hussein, 2015: 1). Blended learning is a knowledge transfer program that utilizes more than one method to provide information to students (Garrison in Hamid, 2019).

The learning characteristics are as follows:

1. Supplementary resources for study programs.

2. Transformativethe level of learning practice is supported by in-depth learning tools.

3. A holistic view of technology to support learning. 
As for these characteristics, this learning strengthens direct learning through virtual learning tools that can help learning more effectively and efficiently.

\subsection{Google Classroom}

Google Classroom(in Indonesian, namely the Google Classroom) is an application to find solutions to difficulties in making and sharing each paperless assignment, especially during the current COVID-19 pandemic. This software has been introduced as a feature of Google Apps for Education since August 12, 2014.

This application provides a discussion space personal between students and teachers. Giving assignments without paper makes it easier for teachers to correct and doesn't waste paper too much which will be used for a test or something without having to meet face to face.

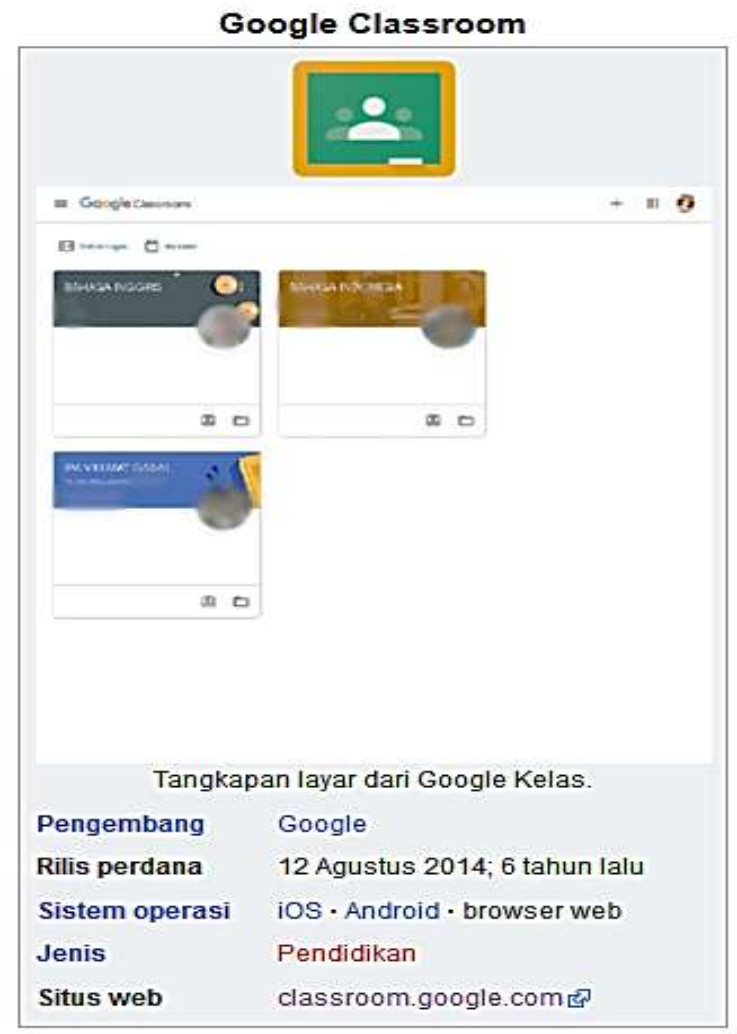

Figure 1. Google Classroom Icon

\subsection{Capabilityan Mathematical Representation}

Mathematical representation Capabilityan is one of the general goals of learning mathematics in schools. This ability is very important for students and is closely related to communication and problem solving skills. To be able to communicate something, someone needs a representation in the form of pictures, graphs, diagrams, or other forms of representation. In line with the opinion (Zhe, 2012: 63-76) "The structure of language in mathematical activities includes external communication such as written and oral representation of symbols, words, graphics, and images". Mathematical skills are associated with communication skills in any process of mathematical activities that involve external communication, such as written representation skills and oral representations in graphics, words, symbols and pictures. By representation, originallya looks difficult and complicated can be seen more easily and simply, so that the problems presented can be solved more easily. 
Menaccording to the National Council of Teachers of Mathematics(NCTM, 2000) There are five standard processes that students need to have and master in learning mathematics, namely: (1) problem solving; (2) reasoning and proof (reasoning and proof); (3) communication (communication); (4) connections; and (5) representation.

\subsection{Mathematical Resilience}

Resiliency in general is universal capacity disappearallow a person, group or community to prevent, reduce or overcome the damaging effects of adversity (Ariyanto, Tsalatsa, \& Prayito, Analysis of Free Orientation and Student Resilience in the Mathematics Learning Media Development course, 2018: 30) According to Grotberg, resilience is a person's ability to judge, overcome, and improve themselves or change themselves from adversity or misery in life, because every person must have a difficulty or a problem and no one lives in the world without a problem or difficulty.

Sujarwo stated that resilience is the individual's capacity to deal with and overcome and respond positively to unpleasant conditions that cannot be avoided, and take advantage of those unpleasant conditions to strengthen oneself so as to be able to change these conditions into something normal to overcome (Krisnaya, Antari, \& Dantes, 2014: 4).

Henderson \& Milstein pointed out the characteristics of resilient adolescents yaitu individuals who are socially competent and have life skills such as: problem solving, critical thinking, the ability to take initiative, awareness of goals and positive future predictions for themselves. They have special interests, direct goals, and motivation to excel in school and in life (Setiantanti, 2017: 184).

Resiliency is seen as an individual capacity that develops through the learning process. Through various successes and failures in facing difficult situations, individuals continue to learn to strengthen themselves so that they are able to change stressful and unpleasant conditions into reasonable conditions to be overcome (Krisnaya, Antari, \& Dantes, 2014).

\subsection{Early Math Ability}

According to the Indonesian dictionary (2008: 979) "ability is the ability, proficiency or strength and the beginning is the very beginning or the beginning". So it can be interpreted that the initial ability of students is the ability or skills that students have before participating in the learning that will be given. According to (Rusman, 2014: 158) "Knowledge of students' initial abilities is important for teachers to be able to provide appropriate and useful portions of lessons to take the necessary steps". The initial ability of mathematics describes the readiness of students in doing mathematics learning activities. Another thing is explained by (Astuti, 2015: 71) that initial knowledge is a framework in which students filter new information and look for meaning about what is being learned in the learning process. In understanding the material, prior knowledge is the main factor that will influence the learning experience for students. Each individual has different learning abilities. (Russefendi, 2006: 113) states that from a group of randomly selected students (not specifically selected) there are always a number of high, medium and low-ability children who are normally distributed. Students' initial mathematical abilities are important to know before starting with their learning, because then it can be seen whether students already have or knowledge which is a prerequisite for following their learning. The extent to which students already know what material will be presented. By knowing this, the teacher will be able to better design learning. Because if students are given material that has been known, they will feel bored quickly. 


\section{Research Methods}

This type of research is Quasi Experimentto examine the ability of mathematical representations and students' resistance to the application of learning using blended learning based on google class room. Learning is carried out by applying blended learning to the experimental group and regular learning carried out by the teacher (direct learning) in the control class.

This research was conducted in class VII SMPIT Ulil Albab Pematangsiantar in the odd semester of the 2020/2021 academic year. It will be held in November 2020. The reason for choosing this location is because the availability of learning resources at this school is sufficient to conduct research using blended learning in accordance with the current state of the COVID-19 pandemic. The learning that has been carried out in these schools is still dominated by teachers while students are passive and students' math skills are still low.

\section{Discussion}

To answer the research questions raised in the introduction, it is necessary to analyze the research data. The analysis in question is to determine the effect of google classroombased blended learning on students' mathematical representation abilities and resilience. The experimental class carried out learning with blended learning while the control class carried out learning by direct learning or by learning that was usually carried out by the teacher. Furthermore, it will also look at the interaction between learning (blended learning based on google classroom and ordinary learning) with initial mathematics abilities (high, medium and low) on the ability of mathematical representation and student resilience.

The Initial Mathematics Ability Test (KAM) was given to determine the average equivalence of the experimental class and the control class. This test is also conducted to classify students based on high, medium and low KAM. To get an overview of the students' KAM, the mean and standard deviation were calculated. The complete calculation results can be seen in the attachment, while the summary results are presented in Table 1 below:

Table 1. Description of Students' Initial Mathematics Ability Based on Learning

\begin{tabular}{|c|c|c|}
\hline \multirow{2}{*}{ Statistics } & \multicolumn{2}{|c|}{ Learning } \\
\cline { 2 - 3 } & Blended Learning & Conventional Learning \\
\hline $\mathbf{N}$ & 16 & 17 \\
\hline Average & 67.50 & 64.31 \\
\hline $\begin{array}{c}\text { Standard Deviation } \\
\text { (Standard Deviation) }\end{array}$ & 10.65 & 13.53 \\
\hline
\end{tabular}




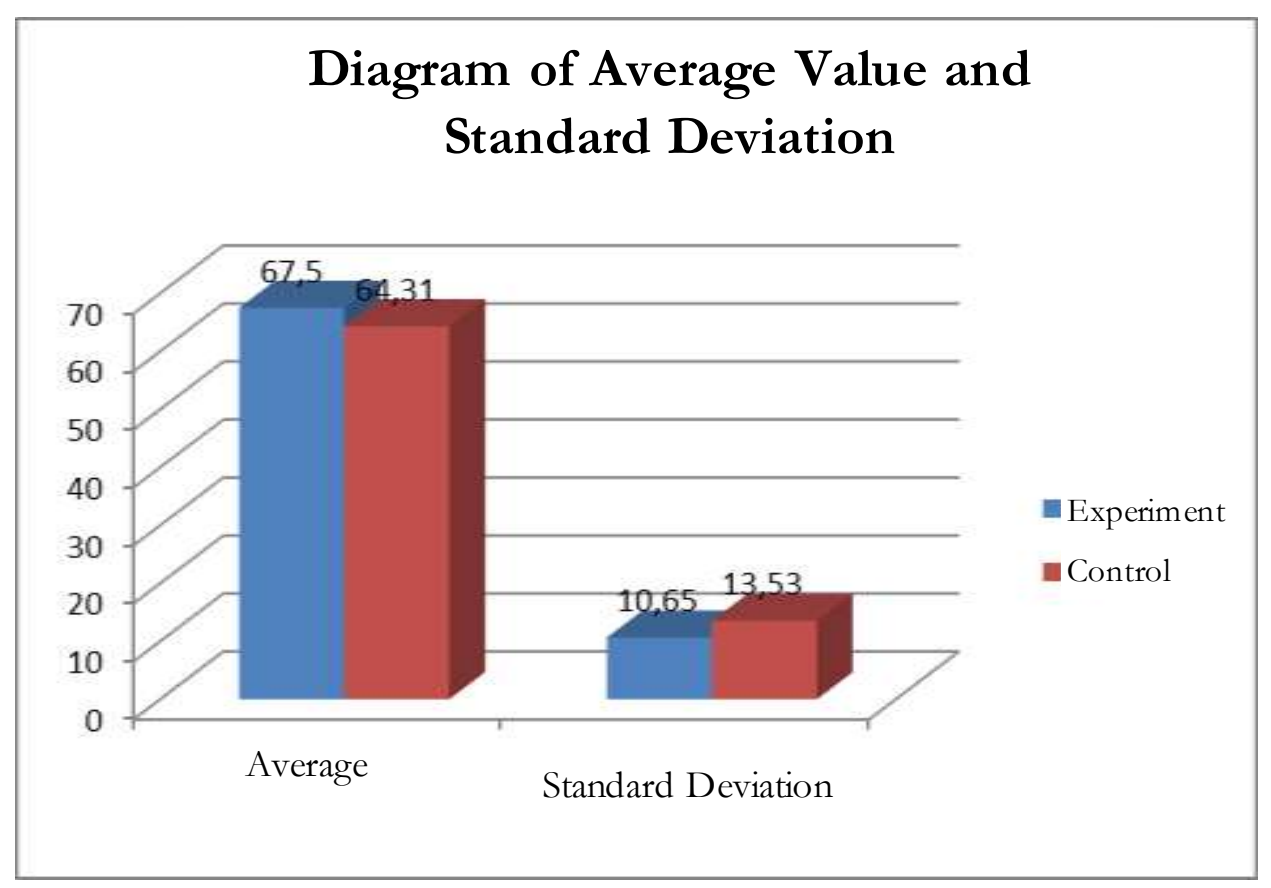

Figure 2. Diagram of Average and Standard Deviation of KAM Test Results for Experiment Class and Control Class Students

Furthermore, the students' initial mathematical abilities (high, medium, low) were grouped based on the scores obtained by the students. For students whose scores were grouped in high initial mathematics ability, students who had grades were grouped in moderate mathematics initial ability, and students who had KAM scores were grouped in low initial mathematics ability. In the experimental class the values of and, so and, while for direct learning the values of and, so and. The results of the complete calculation can be seen in Appendix E, while the summary results are presented in Table 2. below:

$K A M \geq \bar{X}+S D \bar{X}-S D<K A M<\bar{X}+S D \leq \bar{X}-S D \bar{X}=67,5 S D=10,31 \bar{X}+S D=$ $77,81 \bar{X}-S D=57,19 \bar{X}=64,31 S D=13,12 \bar{X}+S D=77,43 \bar{X}-S D=51,19$

Table 1. Data of Students' Initial Mathematics Ability

\begin{tabular}{|c|c|c|c|}
\hline \multirow{2}{*}{$\begin{array}{c}\text { Research Sample } \\
\text { Class }\end{array}$} & \multicolumn{3}{|c|}{ Students' Initial Mathematics Ability } \\
\cline { 2 - 4 } & High & Moderate & Low \\
\hline Experiment Class & 3 & 10 & 3 \\
\hline Control Class & 3 & 11 & 3 \\
\hline amount & 6 & 21 & 6 \\
\hline
\end{tabular}

One of the requirements in quantitative analysis is the fulfillment of the assumptions on the normal distribution of the data to be analyzed. The formulation of the hypothesis to test the normality of the KAM data is:

$H_{0}$ : Samples come from populations that are normally distributed

$H_{1}$ : Samples come from populations that are not normally distributed 
The test criteria used is the value of significance (sig.) Greater than it is accepted. The data normality test used the Kolmogorov-Smirnov test. The results of the calculation of the KAM data normality test for students in the experimental class and control class can be seen in Table 3. below: $\alpha=0,05 H_{0}$

Table 2. Results of Normality Test of Students' Initial Mathematics Ability Tests of Normality

\begin{tabular}{|l|r|r|r|r|r|r|}
\hline & \multicolumn{3}{|c|}{ Kolmogorov-Smirnova } & \multicolumn{3}{|c|}{ Shapiro-Wilk } \\
\cline { 2 - 7 } & Statistics & df & \multicolumn{1}{c|}{ Sig. } & Statistics & \multicolumn{1}{c|}{ df } & \multicolumn{1}{c|}{ Sig. } \\
\hline KAM Value Experiment Class & .157 & 16 & $.200 *$ & .940 & 16 & .350 \\
Control Class KAM Value & .150 & 16 & $.200 *$ & .918 & 16 & .157 \\
\hline
\end{tabular}

*. This is a lower bound of the true significance.

a. Lilliefors Significance Correction

From Table 3, the value of significance is greater than the level of significance (sig). This means that the KAM data from the two sample groups are normally distributed. From these data, it is obtained that the KAM value in the experimental class and control class has a significance value greater than 0.05 , namely $(0.200>0.05)$ and $(0.200>0.05)$, the KAM data is normally distributed both in the experimental class and in the class. control. $\alpha=0,05$

The test of students' mathematical representation ability is the final or posttest test in this study. The mathematical representation ability test is in the form of essay questions related to the material being experimented on, namely algebraic material. The questions consisted of 4 questions representing 3 (three) indicators of mathematical representation ability, namely: (1) Visual representation indicators, with measured competency indicators that students were able to present data or information from a visual representation (image) to solve everyday problems. days that involve algebra in question number 3, (2) Indicators of representation of mathematical equations or expressions, with the measured representation indicators, students are able to make mathematical equations or models from the representations given in question number 4 .

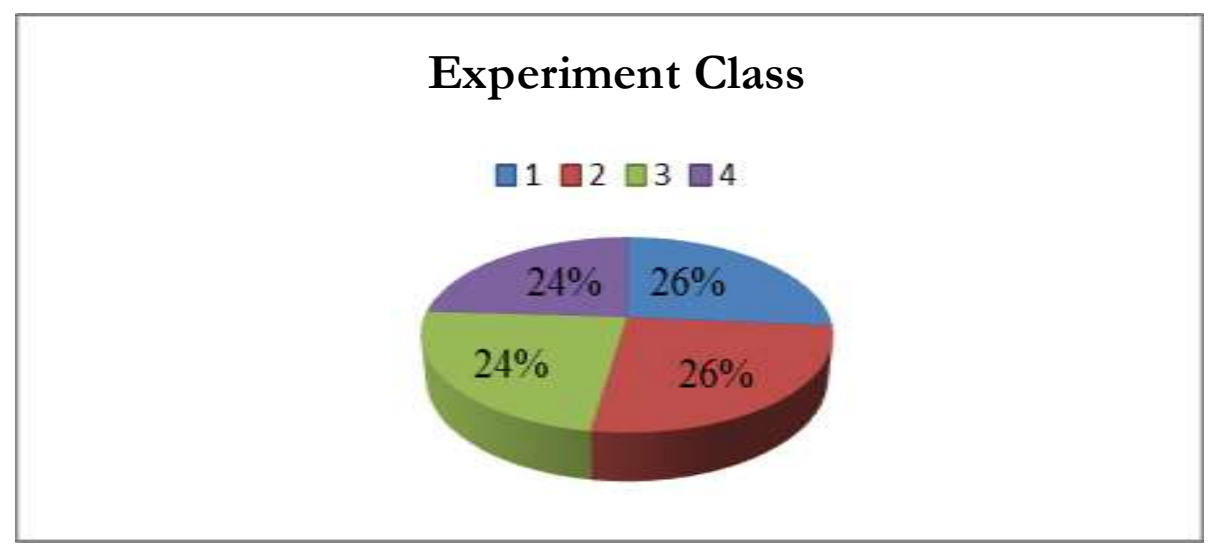

Figure 3. Diagram of Mathematical Representation Ability in Experiment Class

Based on Figure 4.2, it can be explained that the mathematical representation ability using blended learning based on google classroom based on the achievement of each indicator in each question has a percentage of $26 \%$ on question number $1,26 \%$ on question number 2 , $24 \%$ on question number 3 and $24 \%$ on question number 4 . So it can be concluded that the indicator of the most controlled questions Students in the experimental class are questions 
number 1 and 2. For the summary percentage results of students' achievements in the control class can be seen in Figure 4 below:

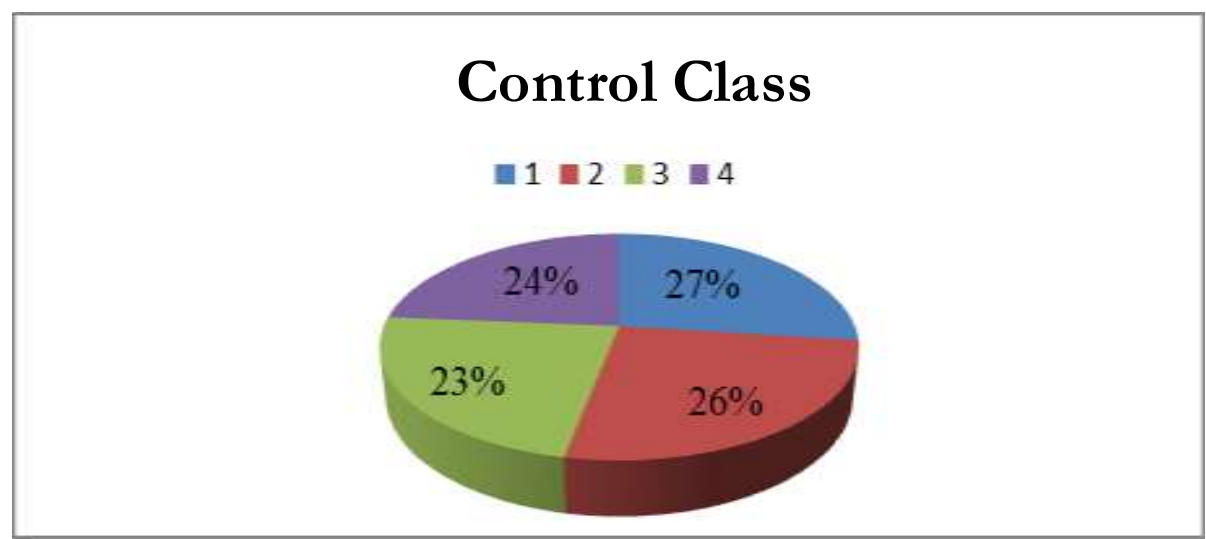

Figure 4. Representation Ability Diagram of Students in Control Class

The summary presentation results of the students' achievements in the experimental class can be seen in Figure 5. below:

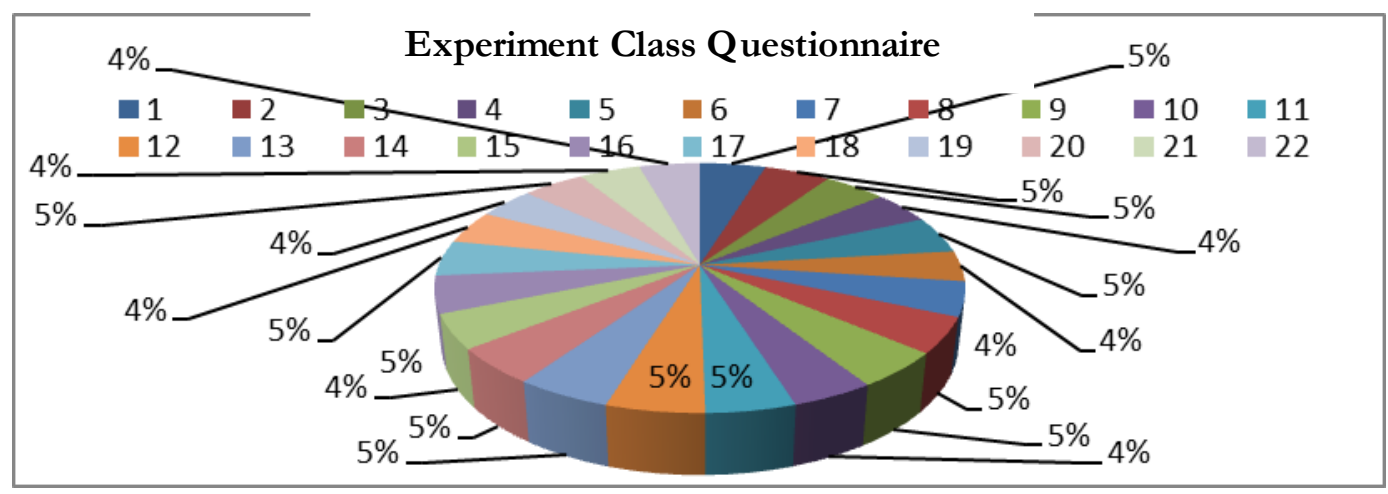

Figure 1. Student Resilience Ability Questionnaire Diagram in the Experiment Class

Based on Figure 4.5, it can be explained that the resilience abilities of students being taught use blended learning based on google classroom based on the achievement of each indicator on each question has a $5 \%$ percentage on questionnaire questions number $1,2,5,8,9,12,13,16,20,22$ and has a percentage of $4 \%$ on questionnaire question number 3,4 , $6,7,10,11,14,15,17,18,19$ and 21 . For the summary percentage results of student achievement in the control class can be seen in Figure 6 below: 


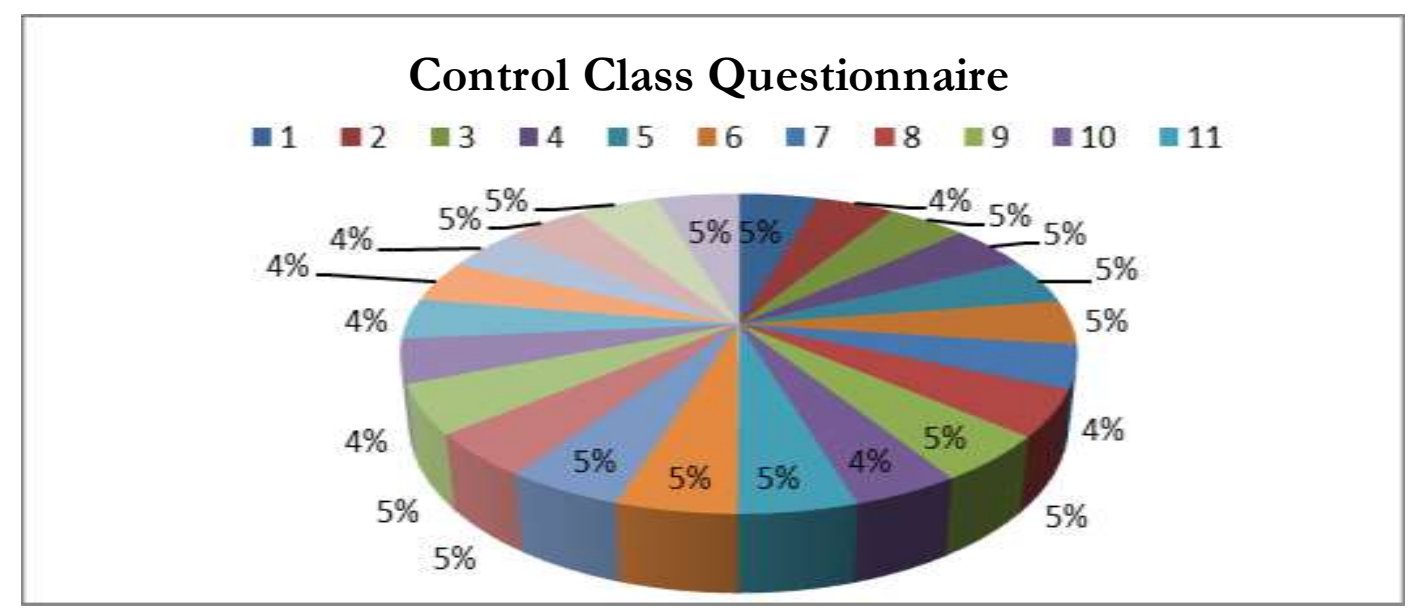

Figure 2. Student Resilience Ability Diagram in Control Class

Based on Figure 6, it can be explained that the resilience ability of students who are taught using conventional learning based on the achievement of each indicator on each question has a $5 \%$ percentage on questionnaire questions number $2,3,8,10,11,12,13,15,16,20,21,22$ and has a percentage of $4 \%$ on questionnaire questions number $1,4,5,6,7,9,14,17,18$ and 19 .

Table 4. Description of the Resilience Ability Questionnaire Data for the Second Learning Groups

\section{Learning Model * KAM}

Dependent Variable: Value

\begin{tabular}{|c|c|c|c|c|c|}
\hline \multirow[t]{2}{*}{ Learning model } & \multirow[t]{2}{*}{ KAM } & \multirow[t]{2}{*}{ Mean } & \multirow{2}{*}{$\begin{array}{l}\text { Std. } \\
\text { Error }\end{array}$} & \multicolumn{2}{|c|}{$95 \%$ Confidence Interval } \\
\hline & & & & $\begin{array}{l}\text { Lower } \\
\text { Bound }\end{array}$ & $\begin{array}{l}\text { Upper } \\
\text { Bound }\end{array}$ \\
\hline \multirow{3}{*}{$\begin{array}{l}\text { Blended Learning } \\
\text { Learning Based on } \\
\text { Google Classroom }\end{array}$} & High & 80,000 & 7,745 & 66,161 & 93,839 \\
\hline & & 67,333 & 1,741 & 63,760 & 70,907 \\
\hline & Low & 52,000 & 6,745 & 38,161 & 65,839 \\
\hline \multirow{3}{*}{ Conventional Learning } & High & 78,000 & 6,745 & 64,161 & 91,839 \\
\hline & $\begin{array}{l}\text { Moderat } \\
\mathrm{e}\end{array}$ & 65,929 & 1,803 & 62,230 & 69,627 \\
\hline & Low & 53,000 & 6,745 & 39,161 & 66,839 \\
\hline
\end{tabular}

In table 4 , it can be seen that the average resilience ability of the two groups of students was taught using blended learning based on google classroom and conventional learning. In blended learning based on google classroom, the average ability of resilience is 66.43, while students who receive conventional learning get an average of 65.64.

\subsection{Normality 'Test of Students' Mathematical Resilience Questionnaires}

The following is the hypothesis formulation to test the normality of the data:

$H_{0}$ : Samples come from populations that are normally distributed

$H_{1}$ : Samples come from populations that are not normally distributed 
The test criteria used is the value of significance (sig.) Greater than it is accepted. The data normality test used the Kolmogorov-Smirnov test. The results of the calculation of the normality test of the questionnaire data on the mathematical resilience of students in the experimental class and control class can be seen in Table 4.9 below: $\alpha=0,05 \mathrm{H}_{0}$

Table 5. Results of Normality Test for Students' Mathematical Resilience Questionnaires

\section{Tests of Normality}

\begin{tabular}{|l|r|r|r|r|r|r|}
\hline & \multicolumn{3}{|c|}{ Kolmogorov-Smirnova } & \multicolumn{3}{|c|}{ Shapiro-Wilk } \\
\cline { 2 - 7 } & Statistics & \multicolumn{1}{c|}{ Df } & \multicolumn{1}{c|}{ Sig. } & Statistics & df & \multicolumn{1}{c|}{ Sig. } \\
\hline $\begin{array}{l}\text { Questionnaire Class, } \\
\text { Experiment } \\
\begin{array}{l}\text { Questionnaire Class } \\
\text { Control }\end{array}\end{array}$ & .140 & 16 & $.200 *$ & .942 & 16 & .379 \\
\hline
\end{tabular}

*. This is a lower bound of the true significance.

a. Lilliefors Significance Correction

Table 5 shows that the questionnaire score data on students 'mathematical resilience abilities in the experimental class and control class has a significance value greater than 0.05 , namely $(0.200>0.05)$ and $(0.200>0.05)$, then the questionnaire data on the students' resilience ability for learning which uses blended learning based on google classroom and conventional learning with normal distribution.

Similar to hypotheses one and three, research hypotheses two and four were analyzed using two-way ANOVA. The statistical test with two-way ANOVA is used to test whether or not there is an effect of google classroom-based blended learning on students 'mathematical resilience abilities, as well as whether or not there is an interaction between learning and students' initial mathematical abilities (high, medium and low) on mathematical resilience abilities students.

Hypothesis 2: Testing the second research hypothesis, namely whether there is an effect of google classroom-based blended learning on students' mathematical resilience abilities.

Statistical model $X_{i j k}=\mu+\alpha_{i}+\beta_{j}+(\alpha \beta)_{i j}+\varepsilon_{i j k}$

Statistically, the hypothesis can be formulated:

$$
\begin{aligned}
& H_{0}: \beta_{21}=\beta_{22}=0 \\
& H_{1}: \beta_{21} \neq \beta_{22} \neq 0
\end{aligned}
$$

\section{Information:}

- $\beta_{21}=$ The effect of google classroom-based blended learning on students' mathematical resilience abilities

- $\beta_{22}=$ The effect of conventional learning on students' mathematical resilience abilities.

Hypothesis 4: The hypothesis of this study examines whether there is an interaction between learning (google classroom-based and conventional blended learning) and the initial mathematical ability of students' mathematical resilience abilities.

Statistical model $X_{i j k}=\mu+\alpha_{i}+\beta_{j}+(\alpha \beta)_{i j}+\varepsilon_{i j k}$

Statistically, the hypothesis can be formulated: 


$$
\begin{aligned}
& H_{0}:(\alpha \beta)_{i j}=0 \\
& H_{1} ;(\alpha \beta)_{i j} \neq 0 ; i=1,2,3 ; j=1,2
\end{aligned}
$$

\section{Information:}

is the influence of the interaction between learning (google classroom-based blended learning and conventional learning) and KAM on students' mathematical resilience abilities. $(\alpha \beta)_{i j}$

Table 6. R-Square Value The Effect of Learning on Mathematical Resilience Ability Model Summary

\begin{tabular}{|l|r|r|r|r|}
\hline Model & \multicolumn{1}{|c|}{$\mathrm{R}$} & $\mathrm{R}$ Square & $\begin{array}{c}\text { Adjusted R } \\
\text { Square }\end{array}$ & $\begin{array}{r}\text { Std. Error of } \\
\text { the Estimate }\end{array}$ \\
\hline 1 & $.356 \mathrm{a}$ & .127 & .069 & 6.58479 \\
\hline
\end{tabular}

a. Predictors: (Constant), Learning Models, KAM

Based on Table 4:12 above, it can be seen that the coefficient of determination RSquare is 0.127 . The R-Square value of 0.127 comes from the squaring of the correlation coefficient or "R", namely the amount of the coefficient of determination (R-Square) is 0.127 or equal to $12.7 \%$. This shows that $12.7 \%$ of the dependent variable (mathematical resilience ability) affects the independent variable (blended learning based on google classroom and conventional) while $87.3 \%$ is influenced by other variables outside this regression equation or variables that are not researched. $0,356 \times 0,356=0,127$

The large result of the influence which is only $12.7 \%$ has possible causes, including (1) student activeness, (2) less meeting intensity due to the COVID-19 pandemic, (3) Internet network and (4) Model and language used teacher.

\section{Conclusion}

1. 'There is an effect of google classroom-based blended learning on students' mathematical representation abilities ( $p$-value. $=0,014<0,05$ )

2. There is an effect of google classroom-based blended learning on students' mathematical resilience abilities ( $\mathrm{p}$-value. $=0,019<0,05$ )

3. There is no interaction between learning (google classroom-based and conventional blended learning) with the initial mathematical ability of students' mathematical representation abilities ( $\mathrm{p}$-value. This proves that there is no joint influence contributed by learning (google classroom-based and conventional blended learning) with the initial mathematics ability (high, medium, low) to the mathematical representation ability of students. $=0,550>0,05$ )

4. There is an interaction between learning (google classroom-based and conventional blended learning) with the initial mathematical ability on students' mathematical resilience abilities ( $\mathrm{p}$-value. This proves that there is a mutual influence that is contributed by learning (google classroom-based and conventional blended learning) with the ability early mathematics (high, medium, low) on students' mathematical resilience abilities. $=0,030<0,05$ )

5. The magnitude of the effect of google classroom-based blended learning on mathematical representation abilities is 0.194 . This means that the effect of the independent variable on changes in the dependent variable is $19.4 \%$, while $80.6 \%$ is 
influenced by other variables outside this regression equation or variables that are not studied.

6. The magnitude of the effect of google classroom-based blended learning on mathematical resilience is 0.127 . This means that the effect of the independent variable on changes in the dependent variable is $12.7 \%$, while $87.3 \%$ is influenced by other variables outside this regression equation or variables that are not studied.

\section{References}

Akramunnisa, \& Sulestry, A. I. (2016). Analisis Kemampuan Menyelesaikan Masalah Matematika ditinjau dari Kemampuan Awal Tinggi dan Gaya Kognitif Field Dependent (FI). Jurnal Pedagogy, 1(2), 46-56.

Alhadad, S. F. (2012). Meningkatkan Kemampuan Representasi Multipel Matematis, Pemecahan Masalah Matematis dan Self Esteem Siswa SMP Mealaui Pembelajaran Dengan Pendekatan Open Ended. Jurnal Penelitian Pendidikan UPI.

Amelia, A. (2013). Peningkatan Kemampuan Representasi Matematis Siswa SMP melalui Penerapan Pendekatan Metakognitif. Bandung: Universitas Pendidikan Indonesia (UPI).

Aminudin, d. (2013). Profil Konsistensi Representasi dan Konsistensi Ilmiah Siswa SMP pada Konsep Gerak, Vol.1, No.3. 3.

Arikunto, S. (2009). Dasar - Dasar Evaluasi Pendidikan. Jakarta: Bumi Aksara.

Ariyanto, L. (2016). Resiliensi Matematis Mahasiswa Calon Guru Matematika. Prosiding Seminar Nasional Pendidikan Matematika Unissula 1:20, 164.

Ariyanto, L., Tsalatsa, A. N., \& Prayito, M. (2018). Analisis Free Orientation dan Resilience Mahasiswa pada mata kuliah Pengembangan Media Pembelajaran Matematika. Jurnal Ilmiah Pendidikan Matematika Volume 3 Nomor 1, 30.

Armanto, D. (2008). Teaching and Learning Multiplication of Multi-Digit Numbers in Realistic Mathematics Education (RME). Jurnal Pendidikan Matematika (Paradikma) 1(1), 14-23.

Astuti, S. (2015). Pengaruh Kemampuan Awal dan Minat Belajar terhadap Prestasi Belajar Fisika. Jurnal Formatif 5(1), 68-75.

Djaali, \& Muljono, P. (2008). Pengukuran dalam Bidang Pendidikan. Jakarta : PT. Grasindo. Dreyfus, T. (2002). Advanced Mathematical Thinking. Mexico: Mexico State Universty.

Fahrurrozi, M., \& Majid, M. A. (2018). Pengembangkan Model Pembelajaran Blended Learning berbasis Edmodo dalam Membentuk Kemandirian Belajar Siswa pada Mata Pelajaran Ekonomi Kelas XI IPS SMAN 1 Selong T.P 2017/2018. JPEK 1, 57-67.

Fatchurahman, M., \& Pratikto, H. (2012). Kepercayaan Diri, Kematangan Emosi, Pola Asuh Orang Tua Demokratis dan Kenakalan Remaja. Persona, Jurnal Psikologi Indonesia, 79.

Fatimah, A. E. (2016). Peningkatan Kemampuan Pemecahan Masalah Matematis Dan Kemandirian Belajar Siswa SMK Negeri 1 Percut Sei Tuan melalui Pendekatan Differentiated Instruction. MES (Journal of Mathematics Education and Science), 2(1), 11-23.

Fatimah, A. E., Purba, A., \& Siregar, Y. A. (2020). Hubungan Resiliensi Matematis Terhadap Kemampuan Pemecahan Masalah Matematis Mahasiswa Pada MAta Kuliah MAtematika Dasar. Journal of Didactic Mathematics. 1(3), 151-157.

Fitri, S. (2020). Pengaruh Blended Learning Rotation Model Strategi Konflik Kognitif Untuk Meningkatkan Kemampuan Spasial dan Resiliensi pada Siswa. unimeed.edu, 1.

Gartika Rahmasari, R. R. (2013). E-learning Pembelajaran Jarak Jauh di SMA. Bandung: Yrama Widya. 
Hakim, A. B. (2016). Efektifitas Penggunaan E-Learning Moodle , Google Classroom dan Edmodo. I-Statement 2, no.1, 2.

Hamid, A.K., et.al. (2019). Evaluation of Implementation of Blanded Learning Implementation in Universitas Negeri Medan. Britain International of Linguistics, Arts and Education (BIoLAE) Journal Vol.1 (2): 224-231.

Hasratuddin. (2008). Pendekatan Matematika dengan Pendekatan Interaktif. Jurnal Pendidikan Matematika (PARADIGMA), 34.

Hendriana, H. (2014). Membangun Kepercayaan Diri Siswa melalui Pembelajaran Matematika Humanis. Jurnal Pengajaran MIPA, 19, 59-60.

Hima, L. R. (2016). Pengaruh Pembelajaran Bauran (Blended Learning) terhadap Motivasi Siswa pada Materi Relasi dan Fungsi. Ilmiah Pendidikan Matematika 2, no.1 , 36.

Hudiono, B. (2015). Peran Pembelajaran Diskursus Multi Representasi terhadap Pengembangan Kemampuan dan Daya Representasi pada Siswa SLTP. Disertasi pada SPS UPI Bandung. Bandung: Tidak diterbitkan.

Irhamna, Amry, Z., and Syahputra, H. (2020). Contribution of Mathematical Anxiety, Learning Motivation and Self-Confidence to Student's Mathematical Problem Solving. Budapest International Research and Critics in Linguistics and Education (BirLE) Journal Vol 3 (4): 1759-1772.

Kusuma, A. (2011). E-Learning dalam Pembelajaran. Lentera Pendidikan 14, 1.

Malik, A. (2015). Statistika Pendidikan. Bandung: Tidak diterbitkan.

Manurung, P. (2013). Statistika Pendidikan. Jakarta: Halaman Moeka.

Maryam, M. S. (2018). Analisis Kemampuan Penalaran Matematis dan Mathematical Resilience Siswa SMA. Jurnal Program Studi Pendidikan Matematika, Volume 4, No.1, 50.

Nasution, Y.S., Syahputra, E., and Mulyono. (2020). The Development of Learning Instrument Using Problem Based Learning Model to Improve Critical Thinking of Junior High School Students. Budapest International Research and Critics in Linguistics and Education (BirLE) Journal Vol 3 (3): 1501-1508.

NCTM. (2000). A Correlation of Investigation in Number Data And Space to The NCTM Principles and Standards for School Mathematics Grades K-5. NCTM (National Council of Teacher of Mathematics)., 280.

Ningsih, M. L., \& Misdalina. (2017). Peningkatan Hasil Belajar dan Kemandirian Belajar Metode Statistika melalui Pembelajaran Blended Learning. Al-Jabar: Jurnal Pendidikan Matematika, Volume 8, No.2, 156.

Panca, D. B. (2017). Pengaruh Penerapan Tools Google Classroom pada Model Pembelajaran Project Based Learning terhadap Hasil Belajar Peserta Didik . IT-Edu, Volume 2, No.1, 60 .

Purwanto. (2011). Evaluasi Hasil Belajar. Yogyakarta: Pustaka Pelajar.

Putra, A. P. (2015). Pengaruh Penerapan Model Blended Learning Terhadap Prestasi Belajar Sejarah Siswa. Candrasangkala 1.

Rajagukguk, W. (2015). Evaluasi Hasil Belajar Matematika. Yogyakarta: Media Akademi.

Riyanto, Er, K. D., \& Sarwoko, E. A. (2006). "E-Learning Sebagai Model Proses Pembelajaran Berbasis Teknologi Informasi. Seminar Nasional SPMIPA 2006, (pp. 1-7).

Sari, P. (2015). Memotivasi Belajar dengan Menggunakan E-Learning. Ummul Quro 6 (Jurnal Ummul Qura Vol VI, No 2, September, 20-35.

Schwieren, Joachim, Vossen, G., \& Westerkamp, P. (2006). Testing Techniques for Efficient Handling of Programming Exercises in an E-Learning Platform 4 [1]. The Electronic Journal of e-Learning, 87-94.

Setiantanti, T. H. (2017). Pengaruh Resiliensi dan Motivasi Belajar terhada Prestasi Belajar MAtematika pada Siswa SMP. 184.

Sitepu, T. (2019). Cooperative Model in Language Reasoning: Indonesian Language Teaching Materials in Teacher Training and Education Faculty of Muhammadiyah Sumatera 
Utara University. Britain International of Linguistics, Arts and Education (BIoLAE) Journal Vol.1 (2): 51-59.

Srimadevi, T., \& Saraladevi, K. (2016). Decision Making And Self Confidence On Problem Solving Ability Among Higher Secondary Student Studying Mathematics. International Journal of Innovative Research in Science, Engineering and Technology, 3513.

undayana, R. (2014). Statistik Penelitian Pendidikan. Bandung: Alfabeta.

Suparlan. (2005). Dimensi Mutu Pendidikan. Retrieved from www.suparlan.com/v5/pages/post/dimensi-mutu-pendidikan.html

Suprapta, I. N., Suharta, I. P., \& Irawan, I. E. (2016). Faktor-faktor yang mempengaruhi kemampuan pemecahan masalah matematika: pengetahuan awal, apresiasi matematika, dan kecerdasan logis matematis. Prosiding Seminar Nasional MIPA, 69-73.

Wibowo, A. T., Akhlis, I., \& Nugroho, S. E. (2014). Pengembangan LMS (Learning Management System) Berbasis Web Untuk Mengukur Pemahaman Konsep Dan Karakter Siswa. Scientific Journal of Informatics 1, no.2, 127-137.

Zanthy, L. S. (2018). Kontribusi Resiliensi Matematis terhadap Kemampuan Akademik Mahasiswa pada Mata Kuliah Statistika Matematika. Jurnal "Musharofa", 87.

Zhe, L. (2012). Survey of Primary Students Mathematical Representation Status and Study on The Teaching Model of Mathematical Representation. Vol.5, No.1. South China: Normal University at Guangdong. 